\title{
Recurrent Primary Diffuse Large B-Cell Lymphoma of the Central Nervous System
}

National Cancer Institute

\section{Source}

National Cancer Institute. Recurrent Primary Diffuse Large B-Cell Lymphoma of the

Central Nervous System. NCI Thesaurus. Code C157073.

The reemergence of primary diffuse large B-cell lymphoma of the central nervous system after a period of remission. 